\title{
Freedom, self-interest and the urban: From political to post-political economy
}

\author{
Mark Jackson, Mark Hanlen
}

\section{Introduction}

\section{Space, power and governance: emergence of political economy}

- - - - - - - - - - - - - - - - - - - - - - - - - - - - - - - - - -

From his early writings on confinement, Madness and Civilization (1965) and The Birth of the Clinic (1973), Michel Foucault's research has a fundamental concern with space and power, or how an ordering of knowing has its specific correlates in spatial practices. The Clinic is invented at that time in the $18^{\text {th }}$ century when a medical gaze undergoes mutation, such that the space of disease, understood as a disciplined and defined medical discourse, and the space of disease recognized as the locus of a body were found to be allusive to one another, able too easily not to coincide. New practices were required in the developing of a new technique or technology of power, a new instrument for a medical gaze. What concerned Foucault was the difficult register of how things and words find their simultaneous space of encounter, and how what is found to be visible emerges from the invisible. With the Clinic, Foucault is particularly concerned with a spacing of the pathological or how pathologies of living things are brought into the orbit of practices of reason. Thus he notes the mutation in a medical gaze that happens between the mid- $18^{\text {th }}$ century and the early $19^{\text {th }}$ century:

In order to determine the moment at which the mutation in discourse took place, we must look beyond its thematic content or its logical modalities to the region where 'things' and 'words' have not yet been separated, and where-at the most fundamental level of language-seeing and saying are still one. We must examine the original distribution of the visible and invisible insofar as it is linked with the division of what is stated and what remains unsaid. ... We must place ourselves, and remain once and for all, at the level of the fundamental spatialization and verbalization of the pathological, where the loquacious gaze with which the doctor observes the poisonous heart of things is born and communes with itself. (Foucoult 1973: xi-xii)

Foucault here refers to "that full space in the hollow of which language assumes volume and size" (Foucoult 1973: xi). He italicizes 'full' and 'hollow', a kind of reciprocity in which discourse constitutes a doubling and complicating spacing; there is a plenitude construed in the very ways that language hollows out things, filling their radical exteriority with meaning. Language is at once empty and full, a spatialising enigma. Two essential and formative texts for understanding Foucault's trajectory here are his early essay on Maurice Blanchot, "Maurice Blanchot: The Thought from Outside" (1987), along with Blanchot's powerful understanding of space in his collection of essays, The Space of Literature (1982). ${ }^{1}$ There is also Foucault's introduction to the work of Georges Canguilhem on the normal and the pathological, "Georges Canguilhem: Philosopher of Error" (1980). ${ }^{2}$ This conjunction allows recognition of how the said and the unsaid find their possibility in a fundamental spatialisation and verbalisation of the pathological. Foucault suggests that modernity is founded on this essentially biopolitical relation of things to words, that a medical gaze as a regulating and defining discourse enables a complex series of spatial practices, and in fact brings into concert juridical and medical discourses that establish a whole series of spatialisings, from the planning of hospitals as spaces of confinement, to civic ordinances that define building codes related to hygiene and habitation.

That new technique was the Clinic, a certain space for the coincidence of a medical knowledge and a diseased body. With Discipline and Punish (1977), the space of confinement of the prison was developed in terms of a more radical extension of this mutation in visibility. This spatialising of relations of power Foucault termed Panopticism, named after the prison designed by Jeremy Bentham at the close of the $18^{\text {th }}$ century. The Panopticon operates its surveillance continuously and anonymously, allowing anyone to either 
operate it or be subjected to it, via constant self-modification of behaviour (Foucault, 1984: 19):

\begin{abstract}
In short, to substitute for a power that is manifested throughout the brilliance of those who exercise it, a power that insidiously objectifies those on whom it is applied; to form a body of knowledge about these individuals, rather than to deploy the ostentatious signs of sovereignty. (Foucault, 1977: 209)³
\end{abstract}

Panopticism, in short, operates via the very spatial articulations and differentiations of an architectural diagram, which is at once, a diagram of power. Thus buildings and urban structures become recognisable in terms of how they determine - and are recognised - through an exercise of power. This work of Foucault was translated to English especially in the 1980s and had its ripples through the disciplines of architecture, urban planning and urban geography. In the last ten years research undertaken by Foucault during the 1970s and delivered at that time in his lecture courses at the Collége de France has been translated to English. Especially relevant here are the lecture courses delivered in 1977-78, Security Territory Population (2007) and the 1978-79 The Birth of Biopolitics (2008). An initial discussion of these introduces concerns that have been more recently taken up by urban planners, architects and urban geographers in developing revised political ontologies of the urban, as well as revised understandings of the political processes and governmental structures of cities.

\section{Population and security: The birth of liberalism}

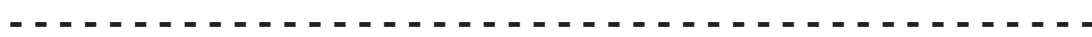

What Foucault especially advances in Security Territory Population is the invention during the $18^{\text {th }}$ century of the very notion of population, as that which a sovereign or monarch needs to primarily manage. Population becomes not the object of security so much as an effect of the application of a new mechanism of power: "Population is undoubtedly an idea and a reality that is absolutely modern in relation to the functioning of political power, but also in relation to knowledge and political theory, prior to the $18^{\text {th }}$ century" (Foucault, 2007: 11). If discipline's target was individuated bodies, security maintains its mechanisms at the level of the milieu and, with techniques of statistics, invents a new horizon of knowing for the agency of those mechanisms in what it comes to name 'population'.

Foucault develops two notions essential for how this particular lecture course develops and how he subsequently addresses the biopolitical in the following year. Those two notions are the 'governmentality' of the State, and the notion of 'apparatuses of security'. During the 1970s Foucault had to do battle with political Marxists for whom power was that which a State held and that which had to be seized from the State, a governmental model that firstly, has an ontology of power-as-substance, as something one possesses and, secondly, the governmentality of a State understood from the model of monarchical power: a head who holds power, whether the body of the king or an elected representative of a people. Foucault's disagreement with both of these notions was fundamental. This becomes the basis of his understanding of the governmentality of the State, where government itself becomes that which needs to be managed in a complex exercise of power with no centrality.

$U_{\text {nder }} 1^{\text {th }}$-century Mercantilism, European States developed a reliance on statistics precisely as that which could measure the distributions of individuated bodies and things in a regime known as Raison d'Etat, whose political mechanism was termed Police and ensured for a sovereign an inventory or visibility of all things within a territory. However, what became increasingly obvious was the necessity to account for not the accumulation of individuated bodies under disciplinary mechanisms of spatial confinements, but an aleatory body, population itself, which seemed, when engaged statistically, to have its own laws that were simply not visible or apparent to a monarch. Population was an opacity that could not be governed by disciplinary tactics, though was increasingly understood as that which must necessarily be governed. Hence, in Foucault's terms, there emerged the attenuation of sovereign power and the birth of the biopolitical management of population, coincident with the necessary invention of political economy. Such relations gave rise to economics as precisely that discipline that determined the peculiar laws of population whilst in turn became governed by population's statistical measures. These tensions saw the 'birth' of liberalism as a governmental reason to radically question the centrality of sovereign power or the centrality of a State's governance. The name Foucault gives to this new regime is 'apparatus of security'. It is security defined in terms of forecasting via economics, statistics and population as key constitutive figures of what will happen: the fundamental predictive and planning measures in the governmentality of a State. In this sense, government itself may well be posed as an obstacle to good economic planning. Probability theory, concern with risk and its management, became the key concern of State management, and a primary organising force, or base rationale of urban management. In this, the art of government and the definition of the sovereign and the sovereign State, coupled with the exclusive role of Police in the formation and governance of towns, also undergo fundamental transformations, as does a concern with what the space of government entails. It is here that governmentality emerges for Foucault and with it a new understanding of the civic, the social, the urban, the emergence of civil society and the science of political economy. ${ }^{5}$ The perennial question that liberalism, emerging with political economy at the end of the $18^{\text {th }}$ century, and more so neo-liberalism of the $20^{\text {th }}$ century, asks is: How much can or should centralized government intervene in the State? In its radical forms, neo-liberalism sees any government intervention to be detrimental precisely to those laws that govern population and political economy, which are essentially natural laws, determined by statistical measure.

Foucault emphasizes that while sovereign rule over territory is somewhat eclipsed by the disciplinary mechanisms of Police, a mechanism set apart from, though in the service of, the sovereign, it is in turn eclipsed by emphases on risk and planning, on probability in political economy, yet all three mechanisms maintain a role in the governmentality of the State. His exemplars are urban and taken from the $18^{\text {th }}$ century: the location of the capital of a State, recognised as a decision in territorial strategy; the planning of new towns in France and Sweden, on the model of the Roman camp, concerned with a series of zones of confinement in an orthogonal grid; and the re-modelling of a port-city in order to increase the possibility of the flows and circulation of goods, people and money, primarily a case of speculative investment in a potential future. In short, Foucault suggests that sovereignty capitalises a territory, disciplines structures, and addresses hierarchies of function and distributions of elements, while security plans a milieu "in terms of events or series of events or possible elements, of series that will have been regulated within a multivalent and transformable framework" (Foucault, 2007: 20). With this articulation of security, Foucault's understanding of power as action-upon-action, and as practice within networks and mechanisms, increasingly coincides with an articulation of security as a mechanism of power, constitutive of an immanent milieu.

\section{Self - interest}

$\mathrm{W}$

With security as a mechanism of power there is a fundamental shift in an understanding of competition. No longer is it competition between sovereigns who command a territory, nor is it competition between nation states regulated by the complex web of regulations of the Police who aim to maximise circulation of commodities and production with the State as 
its own end. Whilst the State maintains understanding as fundamentally emanating from the will of the sovereign, what arises is a new agency of competition, linked precisely to the emergence of a new understanding of freedom and a new entity to be the principal target for that freedom:

\begin{abstract}
Competition will be allowed to operate between private individuals, and it is precisely this game of interest of competing private individuals who each seek maximum advantage for themselves that will allow the state, or the group, or the whole population to pocket the profits, as it were, from this conduct of private individuals, that is to say, to have grains at the just price and to have the most favourable economic situation. ... It is now a matter of ensuring that the state only intervenes to regulate, or rather to allow the wellbeing, the interest of each to adjust itself in such a way that it can actually serve all. The state is envisioned as the regulator of interests and no longer as the transcendent and synthetic principle of the transformation of the happiness of each into the happiness of all. (Foucault 2007: 346)
\end{abstract}

Individual interest can no longer come under the gaze of a sovereign will and hence cannot be regulated by Police in the form of disciplinary mechanisms, whose arbitrary interventions happened according to the ratio of a sovereign capability. Yet individual interest follows a regulatory mechanism no less exacting for it being all the more 'natural'. The governing or governmentality of decision happens at the level of a micro-physics of power whose exercise happens through a panoply of new techniques and technologies primarily concerned with understanding the future outcomes of one's immediate and private interests and actions in competition with those of all others. ${ }^{6}$ In short, the question becomes: what does one risk by acting in this way or that? Outside of the regulatory discipline of Police there is nothing prohibiting the freedom of one's actions. That is to say, the sovereign will that commands the welfare of the state is suspended, even if regulation of a judicial nature is still managed by a fundamentally new understanding of 'police'. The new technologies of power come in the form of amassing statistical and probabilistic calculations that inform decision processes concerning market investments, implementation of hygiene measures, inoculation against disease, applying building regulations, registering and licensing professionals, and so on.

\section{The eclipse of political economy}

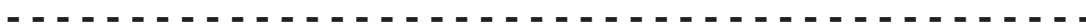

The paper has outlined Foucault's account of the emergence of liberalism within an understanding of State governmentality. The remainder of this paper argues that there has emerged in the $21^{\text {st }}$ century a fundamental mutation to what Foucault defined as apparatus of security or a liberalism that has dominated notions of governmentality in the nineteenth and twentieth centuries, a mutation that implicates a radical shift in an ontology of place leading to considerations for rethinking an ontological disclosure of the urban. This can be seen in applying Foucault's understanding of the governmentality of the State to the 2008 Global Financial Crisis in terms of relating our contemporary global financial structures, themselves driven by the management-or impossibility-of-managing-global derivative debt, to an ontological disclosure of place and event as primordial determinations for urban planning. In tracing through to the present, from post Great Depression legislation in the United States, the extent to which governmental policies on welfare housing, its financing and accessibility, were crucial for determining macro-structural forces in urban development, it is possible to recognise the extent to which neo-liberal policies on housing the poor coincided with the liberalisation of the banking system in the United States. This liberalisation was instrumental for both the 2007-2008 Sub-prime Mortgage Crisis, and the 2008-2009 Global Financial Crisis. This was also coincident with the shift from State-centric approaches to social housing that had become predominant especially after World War Two, to new strategies for housing the poor that occurred with the move from Keynesian economics to neo-liberalism. These offer two distinctly different approaches to the problem of uncertainty and risk. The former takes an interventionist approach that collectively governs through techniques of social insurance, such as health, income guarantee, and housing. Neoliberal approaches sought to individualise these risks with an acceptance of, or belief in, the efficiency of the market, actively encouraging via a series of incentive or disincentive strategies to switch from State services to private enterprises. Private enterprise concerns with individual freedom and self-responsibility aim to minimise what is termed 'moral hazard', such that individuals can set their own level of risk.?

These changing governmental rationalities opened those affected to new uncertainties and new risks. Deregulation of the banking system, coupled with governmental policy that aimed to encourage home ownership, created the 'sub-prime' market, essentially a form of higher-risk mortgage lending. The invention of non-vanilla derivatives, such as 'collateralised debt obligations' (CDOs), allowed higher-risk activities that were vulnerable to economic change. ${ }^{8}$

\section{The end of probability}

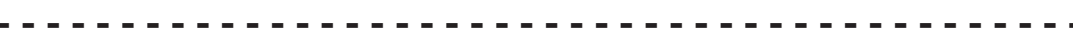

It is especially the economic thinking of Elie Ayache that resonates closely to something fundamental in Foucault's understanding of space, power and the aleatory:

\begin{abstract}
This is a book about writing, pricing and contingent claims. I hold that the writing process and the pricing process are two special kinds of processes that do not take place in possibility or in probability, like the traditional stochastic processes. They fall completely outside prediction. As processes, they keep re-creating themselves and differentiating themselves, yet they do not unfold in chronological time. For this reason, their Swan bird, or the event that gives them wings, is BLANK. It is neither Black nor White; it is neither loaded with improbability nor with probability. It can only be filled with writing, as when we say 'to fill in the blanks'. (Ayache 2010: xv)
\end{abstract}

Elie Ayache wrote a remarkable work on economic theory and philosophical geography in the aftermath of the global CDO failures and the Eurozone national economy defaults. That work, The Blank Swan: The End of Probability, targets the fundamental errors of the major financial institutions who devised derivatives packages in terms of two ontological 
determinants: the very use of probability theory as that which determines the event of pricing, and the ontological disclosure of the locale or place of the event of exchange that becomes determinable via probabilistic models. His thesis essentially concerns a fundamental ontology of place and of exchange, to which he gives the originary name "market." Ayache's argument, or hypothesis, at the outset, is a curious one: pricing, like writing, is outside the domain of probability. It is pure contingency, pure chance. It is for this reason, perhaps, he has as epigraphs to the book two short quotations from French literary and literary-philosophical figures, Paul Valery and Maurice Blanchot. From Blanchot, he quips: "The necessary book is subtracted from chance" (Ayache 2010: iv).

There is something strongly resonant with the peculiar ontology that Ayache brings to bear on what he defines as the place of the market and Foucault's ontology of space, inflecting to the work of Blanchot and what may now define the ontological disclosure of the city. Ayache draws closely in his analysis on the philosophical writing on place by the Heideggerian, Jeff Malpas (Malpas 2004), in order to develop an ontological horizon for understanding place, self, and event in terms other than those of transcendent-transcendental structures; what Malpas adroitly draws out in Heidegger's work up to his 1936-38 Contributions to Philosophy (1999) attempts to arrive at an ontological disclosure of place from the horizonal disclosure of temporality. Ayache recognises uncanny resonance between Malpas's emphasis on the failures of transcendent/transcendental ontologies and the ontologies of derivatives as probabilistic calculability and the event of the market as temporal disclosure, what Malpas identifies in Heidegger as deficiencies in thinking through 'projection' and 'derivation'. Both Malpas and Ayache emphasise an ontological disclosure of immanence, whereby place becomes a milieu of its own non-originary differentiations, as intensive multiplier of the contingent and nonpredictable, that coincides with Foucault's disclosures of place in terms of security's production of immanent milieu. The predominant planning methods of city planners, architects, and urbanists conceive of the city as an object or entity capable of projection and derivation one derives, arrives at or realises through projective planning. It is this transcendent/ transcendental procedure that comes most under scrutiny when the full implications of Ayache's analyses are recognised. It is also here that the full import of Foucault's understanding of place or locale as immanent milieu, coincident with Ayache's notion of 'market' offers a radicalising rethinking of the ontology of the urban.

There is, perhaps, something that happens in the first decade of the $21^{\text {st }}$ century, a movement, paradigm shift even, bringingto a close agovernmental rationality inaugurated with those mutations of the $18^{\text {th }}$ century disclosed by Foucault, those inventions of population and political economy that rendered, or attempted to render transparent, what was opaque to the governmental reason of Mercantile capitalism's Raison d'Ėtat: sovereign surveillance over the territories and disciplined agencies of a State and its subjects. Political economy, biopolitics and governmental techniques of democratic States all emerge and are developed and enhanced with increasing sophistication of techniques of statistics, probability modelling, and planning. The State, its mechanisms and procedures, discourses and agencies become the privileged domain of a series of new design agencies, emerging in the $19^{\text {th }}$ century as the human sciences. The city is their privileged object of empirical enquiry, concentration of potential archives of quarried fact, from which manifold models for development and totalising rationality could be developed. Does this first decade of the $21^{\text {st }}$ century take us to the zenith of this metaphysical construct of idealising worlds, only to demonstrate that the only necessity is contingency, that the end-game of algorithmic calculation of probability modelling of derivative packages was the utter dislocation of a real world and an apparent world? As Nietzsche might say, both worlds have been abolished (Nietzsche 1968). Would this suggest, in the sweep of a Foucauldian gesture, that a new erasing trace of the human is happening on the shoreline of metaphysical certainty, that becoming-human is currently thrown somewhere between the absolute instrumentalism of a market's demands for a self to be its own capital and a self as a work of art, courageously and fearlessly inventing the contours of its existence? ${ }^{9}$ If there is a disconnect between Ayache's market-maker as creative political place-maker and the anonymity of a derivatives debt driver that no-one seems to find stoppable, are we able to respond, which is to say, are we responsible for making our cities, randomly, contingently with a political ethics of the unworkable, or are we unable to respond, response-less, as free self-economic enterprises whose agency is the ongoing calculation of the possible? In what manner can we say the city is open to its derivatives, its technologies of the future?

\section{Writing as aleatory urbanism}

While working in a Foucauldian framework of legal theory, Pat O’Malley's Risk, Uncertainty and Government (2004) undertakes a detailed and genealogical account of how risk and uncertainty, as a series of differential practices, has been thought in terms of governance (O'Malley 2004: 21-26). O'Malley is close to Ayache with respect to an ontological disclosure of events, probability, risk, and uncertainty. For O'Malley, risk and uncertainty are, from governmental perspectives, radically undecidable: "From a governmental standpoint, risks and uncertainties are neither real nor unreal. Rather, they are ways in which the real is imagined to be by specific regimes of government, in order that it may be governed." (O’Malley 2004: 15). Ayache calls this "writing." In this sense, it is by this writing process that urban politics and the build environment are shaped. This inscription process is more akin to Blanchot's ontology of 'attraction' or his spatialising of the 'outside' than it is to the rationalities of urban design's inscriptions. ${ }^{10}$ In agreement with O'Malley on how risk and uncertainty are considered to be fundamental to decision and political processes, the problematic of temporality as "assumed indeterminate future" is fundamental in thinking about liberal freedom. Risk and uncertainty are technologies of freedom, just as they are, for Ayache, technologies of the future. Their genealogies show how our freedoms are shaped by those "who paradoxically claim to know the future" (181).

The paper commenced with the work of Foucault, outlining some fundamental mutations at the end of the $18^{\text {th }}$ century that constituted a transformation to our biopolitical modernity. Key to that was a series of techniques of visibility, from the clinic, to the prison, to the invention of statistics and probability modelling as governmental rationalities for planning or designing the future. The paper concludes with an analysis by Ayache suggesting that these techniques or technologies of visibility defined by probability theory, contemporary algorithms for economic prediction, have failed, rendering invisible precisely what needs to be governed. Questions of the urban, how it is thought, how it is planned and lived are defined by these same determinants that bring into relation fundamental understandings of space and power, as well as design as predictive and derivative procedure, or design as aleatory writing immanent to a particular milieu. That paradox alluded to by O'Malley might better be called design's contingency of freedom. 


\section{Endnotes}

$1 \quad$ Gilles Deleuze (1988) briefly notes Blanchot's influence when discussing Foucault's understanding of the speaking subject: "Here Foucault echoes Blanchot in denouncing all linguistic personology and seeing the different positions for the speaking subject as located within a deep anonymous murmur." (Deleuze (1988: 7). Ann Smock, translator of Blanchot's 1955 The space of Literature (1982), suggests concerning the enigmatic difficulty of approaching the spacings of this 'space': "Although words such as 'region' or 'domain' or 'realm' are often used to designate this zone, it implies the withdrawal of what is ordinarily meant by 'place'; it suggests the site of this withdrawal... No-one enters it, though no one who is at all aware of it can leave: ... it is frequently called le dehors, 'the outside"” (Smock $1982: 10$ ). It is this space that occupies Foucault in determining how words and things find their cohering, how thinking the outside of what has been thought is at all possible. It is this space, or ontology of space that constitutes a radical thinking of the urban.

2 Canguilhem's field of research was the biological sciences, which cannot be formalised in the manner of the physical sciences, or sciences of the inorganic, i.e., with mathematical exactness (Gordon, 1979: 31). Rather, the question of truth and falsity follows a different path, one Canguilhem defines, after Bachelard, as "veridical discourses" (Gordon, 1979: 31). Gordon notes: "[These are] practices governed by the norm of a specified project for the formulation of true propositions. Such discourses are scientific not directly through the actual truth-content of their proposition but through the veridical normativity of their organization as a practice: not their truth but their relation towards a truth" (Gordon, 1979: 31).

It is again important to stress Foucault's recognition of a certain kind of anonymity that operates in the assemblage of panopticism and the processes of subjectification that operate in the locales that may be occupied in the machine. Bentham's Panopticon was a design of great simplicity. A circular ring of prison cells were under continuous surveillance from a guard tower at the centre of the ring. As the guard tower had small viewing openings, prisoners were unaware as to whether or not they were being surveyed, hence incorporating an 'eye' of power as a behavioural restraint.

4 See particularly the work of Ian Hacking on Foucault's engagement with risk, contingency and probability, for example, his 1981 "How should we do the history of statistics?"

$5 \quad$ Much current Foucauldian literature on the city now emphasises the post-civil and post-political as the coincident milieu of neo-liberalism. Dehaene and De Cauter's book on the heterotopic city is sub-titled: Public space and postcivil society (2008). There are also concerns with governmentality of the urban in contexts of the post-democratic and post-political, for example: Cox, 2011; Boyle, 2011; Brand, 2007; Donzolet, 2008; Fairbanks, 2011; Kornberger, 2012; Lemke, 2010a \& 2010b; MacLeod, 2011; MacLeod and Jones, 2011; Murdoch, 2004 .

$6 \quad$ This understanding of interest, self-interest and enterprise recognises some key or fundamental concerns of Foucault: (i) strategic logic as a logic of the contingent relationality of heterogeneous elements in an assemblage that does not seek to bring about an homogeneity or unity but rather aims at a dispersion; (ii) something essential to Foucault's understanding of the heterotopic, and in this to Blanchot's understanding of space, language and self, in that the heterotopic aims at maintaining a relation to all other real spaces outside of a project of totalisation or unification; and (iii) Foucault's concern with eventalisation as the aleatory and uncertain encounter of a visibility irreducible to a statement, and hence recourse to a question of an outside to stratifications of knowing in a question of the anonymity of language's unfinalised functioning and visibility's unformalised matter.

Moral Hazard is the concept that risky behaviour can be caused by insurance. As insurance mitigates the problem of the occurrence of risk or its negative impacts, the insured may engage in further risky behaviour. This further increases the probability of negative-occurrence in turn leading to knock-on effects whereby individual risky behaviour can cause increased cost to society (Rutherford, 1992: 273). See Baker (1996) for a genealogy of the term, which has both a technical insurance meaning and a larger cultural meaning, the former originating in $19^{\text {th }}$-century fire insurance, itself based on earlier marine insurance and the growth of probability theory (Baker 1996: 240). The latter, Baker suggests, frequently appears in op-ed articles in American news media, which takes social welfare (as State funded insurance) as a form of moral hazard. Baker suggests these 'truisms' led to a counterfactual position where the general argument is that less welfare leads to less poverty (Baker 1996: 238).

Derivatives are complex financial instruments such as options or futures, which derive value from other financial assets. These are traded on Futures Markets where traders 'hedge' against future movements in shares or commodities, as a way to minimise uncertainty of future prices. There are also options, which give the trader the option of setting an agreed price that "matures" in the future even if the actual price drops in doing so, thereby minimising risk (Pass, Lowes, \& Davies 2005) Vanilla derivatives or Credit Default Swaps [CDS] typically swap credit risk associated with an entity that may be either corporate or sovereign, which is to say, from one party to another. Exotic derivatives are more complex, moving between different entities and dividable into different levels of risk. These "tranche" groups extend from an AAA rating to the lowest, which is unrated.

If Foucault is correct in his genealogy of the emergence of political economy as that apparatus of security that aimed at measuring the aleatory nature of planning at the heart of what precisely was no longer visible to the monarch, thereby ushering in a fundamentally new exercise of power that he comes to term bio-power, or a power exercised in the defining and ordering of populations by a new science of probability, then the events of the first decade of the $21^{\text {st }}$ century, and theorised by Ayache, point to that moment when political economy faces the opacity of the technologies of visibility it created: a mathematisation of the flows of risk management. By 2008, with the bankrupting of Lehman Brothers and the subsequent $\$ 800$ billion bailout of the Wall Street banks, that very model of governmentality of the State that emerged at the end of the $18^{\text {th }}$ century, a model that had driven the fundamental ontology of the urbanization of populations, is now itself at risk. It is probability theory, determined in the algorithmic functioning of risk management that presents the fundamental risk. This suggests a crisis in determining what might now constitute governmental structures. Hence the turn in political urban theory to post-democratic and post-political paradigms as models, or what Giorgio Agamben suggests as the political disenfranchisement of the refugee, as the viable ethical framework for thinking urban planning outside of the social contract and enlightenment fictions of State-sanctioned and inalienable rights (Agamben, 2003)

10 Foucault notes concerning Blanchot's notion of 'attraction': “It is necessary to be clear about what the word designates: "attraction," as Blanchot means it, does not depend upon any charm. Nor does it break one's solitude or found any positive communication. To be attracted is not to be beckoned by the allure of the exterior; it is rather to suffer [éprouver]-in emptiness and in destitution-the presence of the outside and ... in the fact that one is irremediably outside the outside. Far from calling on interiority to draw close to another, attraction makes it imperiously manifest that the outside is there, open, without depth, without protection or reserve ... but that one cannot gain access to that opening ..." (Foucault, 1998: 154) 


\section{References}

Agamben, G. (2003). Beyond human rights. In E. Cadava. \& A., Levy [Eds.]. Cities without citizens (3-11). Philadelphia: Slought Foundation.

Ayache, E. (2010). The blank swan: The end of probability. Chichester: Wiley.

Baker, T. (1996). On the genealogy of moral hazard. Texas law review, 75, 2, 237-292.

Blanchot, M. (1989). The space of literature (A. Smock, Trans.). Lincoln: The University of Nebraska Press.

Boyle, M. (2011). Commentary: The new urban politics thesis: Rumination on MacLeod and Jones' six analytical pathways. Urban Studies, 48, 12, $2673-2685$.

Brand, P. (2007). Green subjection: The politics of neoliberal urban environmental management. International journal of urban and regional research, 31, 3, 616-632.

Cox, K. (2011). Commentary: From the new urban politics to the 'new' metropolitan politics. Urban studies, 48, 12, $2661-2671$.

Dehaene, M. \& De Cauter, L. [Eds.]. (2008). Heterotopia and the city: Public space in post-civil society. London \& New York: Routledge.

Deleuze, G. (1988). Foucault. Minneapolis: University of Minnesota Press.

Donzelot, J. (2008). Michel Foucault and liberal intelligence. Economy and society, 37, 1, 115-134.

Fairbanks, R. (2011). The politics of urban informality in Philadelphia's recovery house movement. Urban studies, 48, 12, $2555-2570$.

Foucault, M. (1965). Madness and civilisation: A history of insanity in the age of reason. New York: Vintage Books.

Foucault, M. (1973). The birth of the clinic: An archaeology of medical perception. London: Allen Lane.

Foucault, M. (1980b). Georges Canguilhem, philosopher of error (C. Gordon, Trans.). Ideology \& consciousness, 7, 33-36.

Foucault, M. (1987). Maurice Blanchot: The thought from the outside. In M. Foucault. \& M. Blanchot. Foucault/Blanchot (7-60). New York: Zone Books.

Foucault, M. (1977). Discipline \& punish: The birth of the prison (A. Sheridan, Trans.). New York: Vintage Books.

Foucault, M. (2007). Security, territory, population: Lectures at the Collège de France 1977-1978 (G. Burchell, Trans.). New York: Palgrave and Macmillan.

Foucault, M. (2008). The birth of biopolitics: Lectures at the Collège de France 1978-1979 (G. Burchell, Trans.). New York: Palgrave and Macmillan.

Gordon, C. (1979). Other inquisitions. Ideology \& consciousness, 6, 23-46.

Hacking, I. (1981). How should we do the history of statistics? Ideology \& consciousness, 8, 15-26. Also in Burchell, G., Gordon, C. \& Miller, P. [Eds.]. (1991). The Foucault effect: Studies in governmentality (181-196). Chicago: The University of Chicago Press.

Heidegger, M. (1999). Contribution to philosophy: From enowning (P. Emad, K. Maly, Trans.). Indianapolis: Indiana University Press.

Kornberger, M. (2012). Governing the city: From planning to urban strategy. Theory, culture \& society, 29, 2, 84-106.

Lemke, T. (2010a). Foucault, governmentality, and critique. Rethinking Marxism: A journal of economics, culture \& society, 14, 3, 49-64.

Lemke, T. (2010b). Foucault's hypothesis: From the critique of a juridico-discursive concept of power to an analytics of government. Parrhesia, 9, 31-43.

MacLeod, G. (2011). Urban politics reconsidered: Growth machine to post-democratic city? Urban studies, 48,12, 2629-2660. 
MacLeod, G. \& Jones, M. (2011). Renewing urban politics. Urban studies, 48, 12, 2443-2472.

Malpas, J. (2004). Heidegger's topology: Being place world. Cambridge, Mass.: MIT Press.

Murdoch, J. (2004). Putting discourse in its place: Planning, sustainability and the urban capacity study. Area, 36, 1, 50-58.

Nietzsche, F. (1968). "How the 'real world' at last became a myth: History of an error” (R.J. Hollingdale, Trans.), in Twilight of the idols, pp. 40-41. Harmondsworth: Penguin. O’Malley, P. (2004). Risk, uncertainty and government. London: Taylor \& Francis. Pass, C. Lowes, B. \& Davies, L. [Eds.]. (2005). Collins dictionary of economics. Retrieved from http://www.credoreference.com/entry/collinsecon/futures Rutherford, D. (1992). Routledge dictionary of economics. New York: Routledge. 